\title{
SYRIAN MUSLIM REFUGEES IN MALAYSIA: THE NARRATIVES AND SURVIVABILITY
}

\author{
Atika Shafinaz Nazri ${ }^{*}$, Kartini Aboo Talib@Khalid ${ }^{2}$, Nidzam Sulaiman ${ }^{3}$ \\ ${ }^{1}$ Universiti Kebangsaan Malaysia (UKM) Malaysia, e-mail: atikashafinaz@gmail.com \\ ${ }^{2}$ Universiti Kebangsaan Malaysia (UKM) Malaysia, e-mail:k_kbalid@ukm.edu.my \\ ${ }^{3}$ Universiti Kebangsaan Malaysia (UKM) Malaysia, e-mail:nizamm01@hotmail.com \\ *Corresponding Author
}$$
\text { c) (1) (2) }
$$ \\ (C)2019 by the authors. Submitted for possible open access publication under the terms and conditions of the Creative Commons \\ Attribution-ShareAlike 4.0 International License-(CC-BY-SA) (https://creativecommons.org/licenses/by-sa/4.0/) \\ $D$ (do): http://dx.doi.org/10.30983/islam_realitas.v5i2.2106

\begin{tabular}{|l|l|l|} 
Submission: 12 September 2019 & Revised: 29 November 2019 & Published: 10 December 2019 \\
\hline
\end{tabular}

\begin{abstract}
The humanitarian crisis in Syria has impacted the instability in various aspects of security as many as six million of its people have been resettled in foreign countries, including Malaysia. In the survival of protecting themselves, there are obstacles and difficulties encountered in new places. Concerning this matter, the primary purpose of this study sheds light on which elements in the human security paradigm affected Syrian Muslim refugees' survivability in Malaysia. This study was a case study using a qualitative approach. We conducted in-depth interviews with two Global Peace Malaysia (NGOs) officers, three Syrian Muslim refugees, and participant observations around Kajang, Cyberjaya, Ampang, and Shah Alam. Our findings show the survival patterns experienced by Syrian Muslim refugees in Malaysia in the context of human security, which includes personal, political, economic, and community. To protect the refugees' social security, precisely, we would like to suggest the Government of Malaysia come up with an individual action plan to address the refugee-related issues. Also, we recommend the NGOs provide a channel to lodge complaints and psychiatry aid to the refugees, aside from focusing on food, health, and education.
\end{abstract}

Keywords: Human security; NGOs; Survival; Syrians Muslim refugees.

\begin{abstract}
Abstrak
Krisis kemanusian di Syria telah memberi impak ke atas ketidakstabilan dari pelbagai aspek keselamatan sehinggakan enam juta lebih daripada rakyatnya menjadi pelarian di negara-negara luar termasuk berada di Malaysia. Dalam survival untuk menyelamatkean diri terdapat pelbagai halangan dan kesukaran yang perlu dihadapi di tempat baharu. Justeru, permasalahan utama kajian ini adalab untuk. mengenal pasti elemen keselamatan insan yang manakah terjejas dalam survival pelarian Muslim Syria di Malaysia? Kajian menggunakan reka bentuk kajian kes menerusi pendekatan kualitatif. Kaedab temu bual mendalam bersama dua orang pegawai NGO Global Peace Malaysia, tiga orang pelarian Muslim Syria dan pemerhatian turut serta di sekitar Kajang, Cyberjaya, Ampang dan Shah Alam telah dijalankan. Dapatan kajian menunjukkan bentuk-bentuk survival yang dialami oleh pelarian Muslim Syria di Malaysia dalam konteks keselamatan insan adalah melibatkan personal, politik, ekonomi dan komuniti. Dalam melindungi keselamatan insan pelarian, kajian menyarankan agar Kerajaan Malaysia menyediakan satu pelan tindakan khas untuk mengendalikan isu-isu berbangkit mengenai pelarian agar tidak wujudnya penganiayaan terhadap mereka. Kajian turut mencadangkan kepada NGO selain dari bantuan makanan, kesibatan dan pendidikan, NGO boleh menumpukan kepada dua lagi bahagian iaitu menyediakan saluran untuk membuat aduan dan bantuan psikatari.
\end{abstract}

Kata Kunci: Keselamatan insan; NGO; Pelarian Muslim Syria; Survival.

\section{Background}

The official record of refugees who came to Malaysia was recorded in 1975 after the defeat of the Democratic government in Southern Vietnam. Vietnamese fled their homes to avoid any prosecution by the communist regime. They took refuge in Bidong Island, Terengganu. Other neighboring countries namely Indonesia, Singapore, Thailand, and the Philippines were amongst the countries provided a temporary safe hub for Vietnamese refugees. The influx of refugees was massive, and the Malaysian government was concern about the limited resources and safety that could affect the nation. As a result of such interest, the United Nations High Commissioner for Refugees (UNHCR) had established its headquarter in Kuala Lumpur 
officially to manage the Vietnamese refugees' issues ${ }^{1}$.

In the year 1992, the Malaysian government received more than 200 Bosnian refugees placed in Sarawak and Kajang. The federal and state government took the initiative by setting up a Temporary Relocation Program to assist the refugees, and other programs were adopting the Bosnian refugees' children. The humanitarian issues in Bosnia attracted many Non-Governmental Organizations (NGOs) to cooperate with the federal and state government, namely Angkatan Belia Islam Malaysia (ABIM), which established the Malaysian Help Center in Zagreb and Croatia to manage refugees' welfare. The child adoption program went extraordinary for the center operated in Malaysia ${ }^{2}$.

The government of Malaysia is not participatory to the International Refugee Convention of 1951, refugees who find themselves in the country lead a precarious situation on the margins of society, alas it does not have the privilege of granting work permits and free education program ${ }^{3}$. However, the absence of the requirement for visa entrance encourages international refugees to enter Malaysia and settled down. For instance, Syrian refugees especially Muslims chose Malaysia as the place to seek refuge other than Sudan.

Initially, the Syrian refugees seek shelter and improve living standards, but, in the survival, to continue living, there are obstacles and difficulties encountered involving human security $^{4}$, as we stated in the literature review. Alice Edwards's study describes human security and refugee are mutually reinforcing:

"Human security, as a fluid and broadranging concept compatible with human rights and supplementary to international law, maybe one means through which the rights, dignity, and security of refugees can be furthered."

In comparison to the current statecentered international system, which treats refugees as non-persons or strangers, which oppose equality and dependent security receive by all citizens. Alternatively, in a global community facing interdependent and inherently applicable challenges, refugees are treated as equal citizens ${ }^{6}$.

Unfortunately, several countries are repudiating the refugee presence, and it will be an awful situation if in non-signatory 1951 refugee convention's country. Consequently, it could be affected by refugees' human security. According to Paolo Biondi, states' concern towards refugees not merely in economic condition but also gauged in terms of internal security, integration prospects, community interacts, and realpolitik ${ }^{7}$. In this regard, the primary purpose of this study sheds light on which elements in the human security paradigm affected particularly Syrian Muslim refugees' survivability in Malaysia.

4 Benedetta Berti, 'The Syrian Refugee Crisis: Regional and Human Security Implications', Strategic Assessment, 17.4 (2015), 48.

${ }^{5}$ Alice Edwards, 'Human Security and the Rights of Refugees: Transcending Territorial and Disciplinary Borders', Michigan Journal of International Law, 30.3 (2009), 806.

6 Aramide Odutayo, 'Human Security and the International Refugee Crisis', Journal of Global Ethics, 12.3 (2016), 372. <https://doi.org/10.1080/17449626.2016.1251484>.

7 Paolo Biondi, 'Human Security and External Burden-Sharing: The European Approach to Refugee Protection between Past and Present', International Journal of Human Rights, $20.2 \quad$ (2016), 214 <https://doi.org/10.1080/13642987.2015.1103522>. 
This research utilized both primary and secondary data of qualitative method to examine the Syrian Muslim refugees' perceptions, experience, and life story about themselves in Malaysia. The primary data was collected using a structured interview. The sampling method was snowballing because the number of informants gradually increased through recommendation by other respondents who voluntarily sharing their experiences. The list of informants were three Syrian Muslim refugees with UNHCR cards, a member of NGOs from the Global Peace Malaysia (GPM), a schoolteacher from Jasmine Ash-Sham, and it is a school organized by GPM to teach Syrian refugees' children in Malaysia. All the Syrian Muslim informants were giving pseudonyms and a-code with the alphabet letters of A, B, C to protect their identity.

This study applied certain work-ethics while interviewing respondents. The set of structured questions allowed the researcher to gain brief information regarding the interview and the objective of the study. Once, respondents expressed their willingness to participate in this study, subjects asked were simple and clear, the face to face interview demands a researcher to be courteous, not offensive or defensive, and the interview session was pleasant and recorded with permission.

Other than face to face interviews, researchers also observed the residential areas placed Syrian refugees in Kajang, Cyberjaya, Ampang, and Shah Alam. The researchers also visited the schools for Syrian refugees' children in Setiawangasa and the Malaysian Humanitarian Aid and Relief Center (MAHAR) in Sri Rampai, Kuala Lumpur, while helping them with the incoming batch of refugees. This
MAHAR center is an incentive by the government of Malaysia in realizing its mission to bring in three thousand Syrian refugees to Malaysia under a particular program named the Syrian Migrant Temporary Relocation Program starting in the year 2015 until the present.

Also, the secondary data helps to triangulate the primary data based on empirical information and confirmation of documents, mainly from UNHCR. Data triangulation is necessary to build the reliability and validity of the primary data of consistency and to confirm the richness of the data to be used as supporting pieces of evidence for this study ${ }^{8}$. The recorded interviews were transcribed verbatim. The technique of analysis involves themes developed from the transcriptions of the interviews. Themes are building based on the frequency of occurrence of words and similar contexts inside the transcriptions ${ }^{9}$.

\section{The Plight of Refugees in Malaysia}

Refugees resided in countries that are signatory to the Refugee Convention of 1951; they receive a few advantages and benefits stipulated in the convention. On the contrary, such benefits are absent for those residing in countries that are not signatory to the convention. They could experience difficulties adjusting to the new life and local communities.

The works of literature discussed in this section outline the themes showcasing the challenges that refugees experienced, especially amongst the Rohingya. Previous researches on Rohingya are available, and a few scholars

Learning and Teaching Scholars. All Ireland Journal of Teaching and Learning in Higher Education', All Ireland Journal of Teaching and Learning in Higher Education $n$ (AISHE-J), 8.3 (2017), 3353. 
namely Norazira ${ }^{10}$, Intan, et al. ${ }^{11}$, Andika ${ }^{12}$ and Divaghar, and Khadijah, ${ }^{13}$ provided in-depth studies on Rohingya in Malaysia. Meanwhile, Iyad and Rohaiza ${ }^{14}$ discussed the Palestinian Refugee Children's education in Malaysia. However, the case study on Syrian refugees is still absent.

In a case study in Penang, Norazira's research discusses the Rohingya's challenges and reactions toward such problems. A few challenges are unemployment; refugees' children are unable to enroll in school due to the absence of a birth certificate, or those born in Malaysia are not issued with a birth certificate because the couple has no proper identity and document. The refugee status denies them their rights to education, access to health care provision, and state benefit for people living under the poverty line.

Some of them are homeless and live under the bridge, and many have severe health issues, untreated health conditions, and unable to be treated as an outpatient at the hospital or private clinics. Due to poverty, they are homeless life in construction areas, under the bridge, and become beggars. They become an easy target by the local authority to detain them based on illegal immigrants' status and later deported to Myanmar. To overcome such a situation, those Rohingyas with better luck accepted by locals took the initiative to set up an association for Rohingya and assisting their community.

Likewise, according to Divaghar and Khadijah on social harmony among the Karen and Rohingya ethnics in Myanmar refugees' school in Chow Kit, Kuala Lumpur found refugees had been striving to continue their life especially in some aspect such as work, education, health, and residence. For the researchers, the social well-being of the Rohingya and Karen at the Myanmar Refugee School will be achieved if they have the opportunity to penetrate regarding these matters. Social welfare is a critical element in determining to enrich the level of a country and society. All of these elements are aspects of meeting life needs, social mobility opportunities, and managing issues and social. Divaghar and Khadijah suggested implementing intervention and outreach programs for the future of Karen and Rohingya's life to be shielded through entrepreneurship education and primary personal education (hygiene and environment).

Intan et al. argued Malaysia received early Rohingya refugees back in the 1970s, and most of them lived in Selangor especially in Ampang, Gombak, and Hulu Langat. The research revealed most of them were exploited and deceived by locals and ended up being traded in underground human trafficking and lead to death as appeared on mainstream media reports on the Wang Kelian and Padang Besar tragedies at the borders of Perlis and Thailand. Thus, Malaysia and The Association of Southeast Asian Nations (ASEAN) community, together with UNHCR, need to create an action plan and a special task force to counter human trafficking and to assist the Rohingya stateless issue collectively.

13 Divaghar Voothayakumar and Khadijah Alavi, 'Meneroka Kesejahteraan Sosial Karen dan Rohingya di Sekolah Pelarian Myanmar di Chow Kit", Asian People Journal, 2.1 (2019), 1-11.

${ }^{14}$ Iyad Muhammad Eid and Rohaiza Rokis, 'The Barriers to Education among the Palestinian Refugee Children in Malaysia (Halangan Pendidikan di Kalangan Kanak-Kanak Pelarian Palestin di Malaysia', Journal of Islam in Asia , 16.2 (2019), 369-399 <https://doi.org/10.31436/jia.v16i2.714>. Akademika, $\quad 88.1 \quad$ (2018), 5-16 $<$ https://doi.org/10.17576/akad-2018-8801-01>. Sciences Postgraduate International Seminar (SSPIS), 13.2

${ }^{11}$ Intan Suria Hamzah and others, 'Migrasi Rentas Sempadan Etnik Rohingya dan Implikasi terhadap Malaysia', Sains Insani, 01.01 (2016), 36-43 $<$ http://sainsinsani.com/issues/>.

12 Andika A. Wahab, 'The Colours of Exploitation: Smuggling of Rohingyas from Myanmar to Malaysia', 
Another research conducted by Andika explores the Rohingyas' experience as victims smuggled into Malaysia. Such exploitation techniques, namely scamming, forcing, and persuading to hire them as workers or married scammed, were among the stories shared by the victims. Here, the push-pull factors influence the Rohingyas to get involved in such a hoax agreement. The push factor is the condition at their original state, which forces them to leave their country. Present difficulties and massacre committed by the Junta regime and the unrecognition of Rohingya as Myanmar citizens make them stateless and deprived. While the pull factor involves the ideal image of starting a new life in a greener field, yet they were scammed by criminals.

By focusing on education and explores other ethnic refugees' life, research by Iyad and Rohaiza analyses the challenges amongst Palestine refugees' kids that seek knowledge during their transition in the host country, Malaysia. First, they found the main barrier the parents are incapable of sending their children to school due to the financial restraint. In worse circumstances, some children are forced to work because their father is old or sick. Second, the challenges come from the institution itself such as Malaysian Social Research Institute (MSRI) does not provide a strategic education system and the teacher are refugee, leading parents to prevent children from sending to school. The last challenge is parents themselves are lack awareness of education issues. For them, while waiting to be migrated to the third country, education is not essential, and they prefer for the studies to be continued in the third country.

15 Arnold Wolfers, Discord and Collaboration: Essay on International Politics (Baltimore and London: Johns Hopkins University Press, 1962), p. 150.

${ }^{16}$ Ian Bellany, 'Towards A Theory of International Security', Political Studies, 29.1 (1981), $102<$ https://doi.org/10.1111/j.1467-9248.1981.tb01276.x >.

${ }^{17}$ Janis Teivans-Treinovskis and Nikolajs Jefimovs, 'State National Security: Aspect of Recorded Crime',
As a result, life as a refugee in Malaysia is hard, and exposed to many exploitations. They are unable to obtain a working permit, and without proper identification, they are subjected to be detained, trafficked, traded, and abused. Without work and income, they are unable to support their lives and dependents.

\section{Human Security as a Tool to Gauge Refugees' Level of Survivability in Malaysia}

To seek an answer to this research's problem statement, we approached the human security paradigm as a tool to figure out the elements that affected refugees' survivability in Malaysia.

Generally, the human security concept consists of a few aspects namely traditional and non-traditional. This study applies to the field of international relations. Arnold Wolfer's security concept and definition " ... security, in an objective sense, measures the absence of threats to acquired values, in a subjective sense, the absence of fear such values will be attacked... ${ }^{15 "}$ Another scholar Ian Bellany defines security as "Security itself is relative freedom from war, coupled with a relatively high expectation that defeat will not be a consequence of any war that should occur ${ }^{16}$." The idea of human security initially emerged before the cold war (1960-1980), but it was applied mostly to understand and to examine traditional security ${ }^{17}$.

Des Gasper criticized the traditional security concept in his article Securing Humanity: Situating "Human Security" as Concept and Discourse ${ }^{18}$ and supported by Samuel Makinda in Security and Sovereignty in the Asia Pacific, which outlined that the traditional security invented by International 
Relations scholars to avoid security concerns during the cold war ${ }^{19}$. The absence of human well-being, environments, and non-military aspects was compelling and paramount to guarantee safety and security. Samuel Makinda posits when it comes to safety and security, protecting human beings should be the primary concern. There is no official definition yet for the non-traditional security concept because it has been applied in many forms related to the state, non-military, and clear indicators reflecting human and non-human aspects ${ }^{20}$.

Nor Azizan Idris examines the transformation and discourse over traditional security and quotes:

"...security concept transforms especially after the end of the cold war between the United States of America and the Soviet Union; the fell of Berlin Wall in Germany I 1989 was a symbol of the end of ideology separation between democracy and communism, and the end of bipolar between two hegemonic countries of the United States of America and the Soviet Union ${ }^{21}$."

Since the end of the cold war and the fall of the Berlin Wall, the definition of security concept no longer idle within military and state context but evolved into including the politics, economy, and social dimensions in human security discourse ${ }^{22}$. Edward Newman argues the most protruding threat in this world is about 'peace'. Internal issues, namely, disease, hunger, poverty, pollution, climate change, crime, and illicit activities, and extremism, are the post-cold war issues that must be discussed and attended respectively. Security relating to human and non-human is vital in guaranteeing safety to the world ${ }^{23}$.

Scholars that promote human security such as Paul James, Caroline Thomas, Roland Paris, Amitav Acharya, Surin Pitsuwan, Sity Daud, Zarina Othman, Nor Azizan Idris, and Rashila Ramli agree the prerequisite for security is human safety. Paul James defines human security as a preliminary condition for protection, namely, 1) protecting human beings with the material provision, amenities, and infrastructure necessary for them; 2) protecting them from the changing environment to maintain human existentialism and dignity ${ }^{24}$. In other words, Sity et al. argue human security includes a condition which is absent of conflict, it is a fundamental human right, good governance, access to education and health care, and guaranteeing that each human being has an equal chance and choice to live his/her own life ${ }^{25}$. In sum, social security is about protecting lives and creating prosperity away from any threat to life, liberty, and property ${ }^{26}$.

Human security becomes more significant after the United Nations (UN) created a framework about state security and war context with a focus on human security. The structure also describes the consequences of war towards
${ }^{19}$ Samuel M. Makinda, 'Security and Sovereignty in the Asia-Pacific', Contemporary Southeast Asia, 23.3 (2001), 401-419<https://doi.org/10.1355/cs23-3b>.

${ }^{20}$ M. Makinda.

${ }^{21}$ Nor Azizan Idris, 'Dari Pendekatan Realisme ke Perspektif Kritikal: Menyelusuri Kajian Keselamatan Semasa dan Pasca Perang Dingin.', in Keselamatan Nasional Malaysia (Bangi: Universiti Kebangsaan Malaysia, 2012), p. 65.

22 John Baylis, Steve Smith and Patricia Owens, 'The Globalization of World Politics. An Introduction to International Relations', in International and Global Security (United Kingdom: Oxford University Press, 2017), p. 20.
23 Edward Newman, 'Critical Human Security Studies', Review of International Studies, 36.1 (2010),78-79 <https://doi.org/10.1017/S0260210509990519>.

24 Paul James, 'Human Security as a Left-Over of Military Security, or as Integral to the Human Condition', in Human Security and Japan's Triple Disaster (London: Routledge, 2014), p. 87.

25 Sity Daud, Zarina Othman and Rashila Ramli, Human Security \& Peace in Archipelagic Southeast Asia (Bangi: Penerbit Universiti Kebangsaan Malaysia, 2015).

26 Richard W Mansbach and Kirsten L Taylor, Introduction to Global Politics (New York: Routledge, 2008), p. 596. 
state and regional security ${ }^{27}$. Des Gasper advocates four goals for human security, such as (1) Complementing the social development concept, concern about stability over the economy, and human development is essential; (2) Enhancement of the scope relating to human devel; (3) opment concept including physical safety of human beings; (4) Intensifying the scope of security and safety, including state and military, and adding the concern about the physical safety of human beings; (5) Bridging the scope of security and human development towards fundamental needs ${ }^{28}$.

Human security consists of seven elements namely; 1) economic security (absence of poverty); 2) food security (easy access to food); 3) health security (access to health care, and treatment for diseases); 4) environmental security (sustainable development and ecosystem); 5) personal security (protection for human physical away from abuse, torture, war attack, domestic abuse, substance abuse, and homicide/suicide); 6) community security (cultural and identity preservation for minorities); and 7) political security (civil rights, human rights, and protection against political abuse or deprivation).

These seven elements are officially stated on the Human Development Report (UNDP 1994) and further discussed by a few scholars, namely Roland Paris on Human Security: Paradigm Shift or Hot Air that argues the paradigm shift is inevitable due to contemporary issues that are becoming complex and demanding ${ }^{29}$. Besides, Rashila
Ramli and Nor Azizan Idris posit human security poses a new challenge to Malaysia expose to hobbling illicit and trafficking activities due to its entry ports that connect the global network and the lack of monitoring in the system ${ }^{30}$. Amitav Acharya urging the world community to review human security as a vital context in international relations because it is the basis for state relation and the reason for the world to be at peace for the greater good of all living creatures ${ }^{31}$.

Protecting the core values and rights of all being uniquely human will strengthening the functional relationships between states or amongst states and lift the sovereignty of the state as the guardian of the nation. Hence, the state must place the people first and respect its citizens' rights. With human security in the state agenda, it is assuming that the country will lead the nation to unity $^{32}$. Therefore, Elgantina Farruku argues social security reminds the country to be responsible for providing safe spheres and protection for the people besides overseeing security at the borders. States have to be accountable to the people who elected them as representatives of the people to govern the state. A state must attend and manage internal threats earnestly to guarantee a harmonious condition for the people to live $\mathrm{e}^{33}$.

Ilya Sokov clarifies human security is universal because he questions "what ought to be" in examining the well-being of both human and non-human.

"It should be recognized that human security is a universal value, as is "freedom," "equality," "justice,"

27 Sity Daud and Zarina Othman, Politik dan Keselamatan (Bangi: Penerbit Universiti Kebangsaan Malaysia, 2005).

${ }^{28}$ Gasper.

${ }^{29}$ Roland Paris, 'Human Security: Paradigm Shift or Hot Air?’, International Security, 26.2 (2001), 90 <https://doi.org/10.1162/016228801753191141>.

${ }^{30}$ Rashila Ramli and Nor Azizan Idris, 'Keselamatan Insan dalam Konteks Keselamatan Nasional: Isu dan Cabaran dalam Membina Indeks Keselamatan Insan Malaysia.', in Keselamatan Nasional Malaysia (Bangi: Penerbit Universiti Kebangsaan Malaysia, 2012), p. 81.
31 Amitav Acharya, 'Human Security' in John Baylis, Steve Smith and Patricia Owens, The Globalization of World Politics: An Introduction to International Relations (United Kingdom: Oxford University Press, 2017), p. 336.

32 Lucian Ispas, Alin Cîrdei and Catalin Negoescu, 'The Concept of Human Security in International Relations', Land Forces Academy Review, 16.1 (2011), 11.

${ }^{3}$ Eglantina Farruku, 'Redefining Human Security The Case of Albania', Annales. Etyka w Życiu Gospodarcyym, 19.4 (2016), 81-99 <https://doi.org/10.18778/18992226.19.4.06>. 
"dignity" and so on. Only by maintaining the concept of human security will other values and human rights be provided. Thus, human security is part of "vital freedoms," which facilitate further human development, not merely an instrument for keeping them safe. ${ }^{34}$ "

Ilya Sokov further argues the world has to recognize human security as a foundation for perpetuating the safety and security norms and values, which help to respect fundamental human rights. This basis enhances social development and survivability skills.

\section{The Narrative of Syrian Muslim Refugees in Malaysia}

Syria is a country located in the Middle East, bordering Turkey on the north, Iraq in the east, Jordan in the south, and Israel in the southwest. The trip to get to Malaysia requires the Syrian refugees to transit in a few countries, either traveling by air or sea. Most Syrian refugees came to Malaysia by air flight. Based on Fiza Bahar ${ }^{35}$, before the refugees arrived in Malaysia, they shared the perceptions of Malaysia was a Muslim country and absence of knowledge that it is a multi-ethnic nation.

The Syrian community resided in Malaysia even before the war began because some of them predicted war was inevitable due to antigovernment movements were intense before the revolution. Initially, the community entered Malaysia in the year 2013 were people with families and dependents, and male youths who decided not to join the Syrian army or recruited as one. The majority of them were Sunni, and Shiite was the minority. They entered Malaysia with a tourist visa and later applied for a UNHCR refugee card to live legally in Malaysia.

In the year 2011, the Syrian refugees depended solely on UNHCR until a particular
Syrian Migrant Temporary Relocation Program was set up by the Malaysian government to manage refugees, including providing them with a special visa status, which allows them to change their visa status from a refugee to a legal migrant. However, this program is unattractive to some of them, and they are still holding the UNHCR refugee card because they want to be sent to other developed countries such as Germany, Canada, and Australia.

Based on the UNHCR Malaysia Statistic ${ }^{36}$ exhibited in Table 1.1, until August 2019, the total number of refugees ranging from asylum seeker to a refugee in Malaysia is 177,690. Out of this population, Syrian refugees are 3,200 people, the fourth-highest figure in Malaysia. But this total number is excluding the Syrian people who are holding employment visa, student visas, and those who participate in the Temporary Migrant Replacement Program.

Table 1. Total Number of Refugees in Malaysia

\begin{tabular}{cc}
\hline Country & Total \\
\hline Myanmar & 153,770 \\
\hline Pakistan & 6,410 \\
\hline Yamen & 3,460 \\
\hline Syria & 3,200 \\
\hline Somalia & 3,160 \\
\hline Afghanistan & 2,270 \\
\hline Sri Lanka & 1,870 \\
\hline Iraq & 1,360 \\
\hline Palestine & 770
\end{tabular}

Source: UNHCR website

\section{Residential Areas}

According to the interview with Hasrol Sazli ${ }^{37}$, most Syrian refugees lived in big cities like Kuala Lumpur and nearby cities, namely Ampang, Serdang, Kajang, and Cyberjaya, because of these areas populated by significant numbers of Arabian communities. These allow

\footnotetext{
https://www.unhcr.org/en-my/ figures-at-a-glance-inmalaysia.html

37 Hasrol Sazli (Principal of Jasmine ash-Sham's school), Interview $\{20$ February 2019$\}$.
} 
them to adjust faster in their daily activities where middle east ingredients and foods, restaurants, and communication are making them feel at home. The environment is conducive for new refugees to accommodate new surroundings without feeling alienated. Fiza Bahar adds most of them prefer to stay in high-rise buildings particularly condominiums or apartments. They feel safe because these high-rise buildings are fully monitored and secured. The war-torn their trust to the public, kidnapping, and killing were rampant, left them traumatic. Therefore, staying in these types of buildings make them feel safe. Although they do not have enough money to pay for the monthly rent, their priority is safety and security. Respondents express their fearsome feelings:

"We have suffered from severe trauma during the war in Syria, kidnapping, and people disappearing were rampant. "Therefore, we preferred to stay in an apartment or condominium because of the security and safety measured provided in this place when compared to common housing areas [not a gated area or secured by a hired security guard"

Nevertheless, some Syrian refugees have difficulties in adjusting their lives with a present condition. They were elites in Syria and used to live in a mansion and luxury home. These elites have to start new with no assets and cash to carry themselves. War made them unfortunate.

\section{Employment}

In the employment sector, UNHCR identification has a limitation. Though it provides self-identification information, such ID prohibits refugees from working. But they still work to support their families. Additionally, language proficiency is a significant barrier for those who can only speak the Arabic language. Some well-educated refugees may converse in English well, but the majority of them talk in Arabic only.

An interview with Fiza Bahar expressed young refugees aged 13-14-year-old work to support their families, and they are unable to enroll in school. Most refugees work as service workers at local restaurants, tailor, teacher, and salesman. Though they knew the risk and consequence of being detained by authorities, especially the Immigration officers, they are willing to risk everything and ready to be deported. For some elites' refugees, they open an Arabian restaurant offering Arabic cuisine and desserts.

\section{Education}

For refugees' children, most of them enroll in schools managed by the NGOs around Kuala Lumpur. One of the famous schools occupied by Syrian refugees is the Jasmine Ash-Sham school runs by the GPM. The words from Hasrol Sazli explains the situation:

"Overall, the total number of students is approximately 150 pupils, and two of them were from Jordan and Iraq. For children, the registration fee is 50 Malaysian Ringgit, and for the remaining disadvantaged children, the school will find a sponsor to support them. The fees include tuition, transportation, and food."

\section{Culture and Language}

Besides visa and employment issues, other factors, namely different cultures and lack of language proficiency are challenges for Syrian refugees to interact and to engage with local people. Hasrol stated for educated Syrian refugees, could communicate in English with locals, but most of them speak Arabic only. Besides, in Fiza Bahar's words, she added:

"Only a small number of Syrian refugees can speak the Malay language. The big gap is language, and most Syrian speaks Arabic and French as their mother tongue."

Despite proper documentation and identification provided by UNHCR to Syrian refugees, including assistantship from a few NGOs, the refugees are still struggling with their new lives in Malaysia, especially for families with dependents. The level of 
adjustment for survivability is rather challenging.

\section{Issues of Survivability}

Based on the interview transcriptions and participant observation amongst Syrian refugees, this research identifies four factors about human security that becoming an essential challenge for refugees to integrate with people and local systems namely personal, political, economic, and community.

\section{Lack of Platform for Channeling Their Needs and Grievances}

Based on observation, the Syrian refugees do not have access to information to express their grievances and psychological evaluation for the trauma that they had gone through. Besides, the platform to channel their various issues to the local authority is absent. In another situation, for instance, a boy aged 12-year-old, was a victim of sexual abuse, a male religious cleric, a Pakistan origin, was also a child pedophile had molested him and the family was afraid to report to the police because they are new in Malaysia and do not understand how the system work, the family decided to move to another city in Kajang to stop such abuse from recurring.

Another story is about a male youth aged 19-year-old, who committed suicide, jumped from the tenth apartment where he lived. $\mathrm{He}$ had mental issues due to the trauma of war, depression, hardship, a new place, and new life, further depressing his hope about starting a new life from scratch. Also, women refugees are traumatized due to the war, and the feeling remains. Even when they hear firecrackers during the Chinese festival, they thought the familiar sound is open fire and bomb.

Other than the issues discussed above, this research found the bank account is also part of survival needs, and yet they are absent from such facilities. In this modern world, most activities completed online using debit cards, and without bank cards or access to ATM, these refugees have no safe place for their savings. Informant C' $\mathrm{s}^{38}$ opinion describes below"

"Having a bank account is very important. In Malaysia, each transaction activity depends heavily on the Bank. If you need cash, you have to bring a lot of money, and where do you put all your cash, and how are you going to run your daily activity without a bank account?'

\section{Education for Refugees}

Another issue refugee has always demanded the authority to solve is access to education. Most refugees live far away from the schools provided for their children namely, the international school and a particular school for refugees. The hardship extends to not just location but affordability. Observation in Shah Alam displays a low-income family will not afford to send their children to either of these schools. Their monthly income of serving as a server at the Arab restaurants or petrol station is insufficient to pay for the school fees. Their children will have to stay at home and to receive homeschooling. For those fortunate families with independent businesses, they can afford to send their children to International schools in Putrajaya and Kajang.

\section{Encounter with the Local Authority}

Although the refugees have proper identification and document provided like IMM13 by the UNHCR, they are likely to be the target by the local authority, especially police traffic inquiries for their driving license. They are carrying the international driving license, but police traffic declines such ID on the basis that it has temporal limitation up to a year only. To some extent, the irresponsible traffic officer will abuse his power, asking for some cash to dismiss the case. Such bribery experience is shared by informant B:

\footnotetext{
38Informant C (Syrian refugee), Interview $\{24$ February 2019\}.
} 
"I went to a clinic in Petaling Jaya to see a dentist, and the charge was only RM10.00. But on my way home to Cyberjaya, Indian police traffic stopped me and requested my license. The officer said that my license could not be used in Malaysia. Later he threatens me if I don't pay him RM100.00 [a hundred-ringgit Malaysia] he will give me a ticket. ${ }^{39}$ "

The informant did negotiate about his current condition and begged the officer to reduce the amount from RM100 to RM50. In other stories, sometimes they believe that they are following the standard order, but yet they are still the target to receive a ticket from a local enforcement officer without an apparent reason for misconduct. This odd situation makes them feel unsafe and becomes a challenge for their survival in a foreign land. This insecurity feeling is the main reason that is discouraging them from settling down as a permanent resident in Malaysia.

The recurrence experience by other refugees, informant $\mathrm{C}$, said her husband and friend were stopped at the nearby petrol station and was asked to give RM1000 (a thousand ringgit):

"They tried to scare me and took all my passport, UNHCR card, and asked me to follow them. My husband just followed them to an isolated place where there was barely anyone at the public and demanded us RM1000 (a thousand Ringgit Malaysia), we were too scared and gave them our cash."

\section{Cost of Living and Hardship}

Most Syrian refugees face hardship and difficulty adjusting themselves to the new surroundings, especially for those who have no traveling experience or traveling abroad, lack of education and skills. The primary issue is most of them are unemployed due to a lack of skills, knowledge, and language proficiency.
The UNHCR card is insufficient to be counted as the only indicator to land a job for those who tried.

Based on our interview with informant $\mathrm{A}^{40}$, she lives in Cyberjaya with his husband and three kids. They are well aware that they do not have a working permit to allow them to work, but the husband is still working as a server at a nearby Arabic restaurant to support their family. Unfortunately, the husband was detained by a local enforcement officer for working illegally and was sentenced to three months in jail. Once released, with the UNHCR assistant, they moved to another city, Kajang, to start a new life. To have to work to support their growth and this time, they open a kiosk to selling bread at the lower ground of their apartment. In her expression:

"if we got information that the immigration or police are coming for an inspection, my husband will quickly close our kiosk shop and ran upstairs. We will hide because we are so afraid to get caught and detained."

These stories are moving and grant the impression the refugees are struggling to survive, and they are spared with no options to work with to support their families. The consumers' products like rice, cooking oil, sugar, bread, flour, etc. are quite expensive for those unfortunate people who barely have any money to meet ends need, and worst is for a family with numbers of dependents to feed. Observation in Kajang and Cyberjaya found there are families without food in the house, and they beg for assistance from NGOs, and not every request is answered.

Life deprivation amongst Syrian refugees turns them into beggars on the street. For instance, in Bandar Baru Bangi, there are some Syrian beggars with their small kids walking 2019\}.

${ }^{39}$ Informant B (Syrian refugee), Interview $\{20$ June

${ }^{40}$ Informant A (Syrian refugee), Interview $\{26$ February 2019\}. 
around the areas asking for some cash. Their poor appearance said it all to their life misery, homeless, and living on the street with no place to go. Even sad when they are alone in a foreign land, and most of them stay at the nearby mosque. In another story, observation in the MAHAR office found a Syrian elderly aged 68 years old, homeless, carrying with him a big bag, and stays around Masjid India in Kuala Lumpur for months without any assistance from the NGOs or UNHCR.

\section{Local Community and Adjustment Process}

The language barrier has been difficult for Syrian refugees to adapt to multiethnic communities in Malaysia. Consequently, it is hard for them to fill up the available job vacancies and wither them to adjust and to integrate with locals. Most of them work at the Arab restaurant with a small income or work independently as a carpenter, plumber, electrical maintenance, selling female accessories, and teaching local Muslim kids to read Al-Quran from home. They also sell traditional Syrian food from home based on demand. However, such work does not provide a stable income, and they are facing insufficiency and hard to pay the monthly rent to keep their house. Even worst, when the locals are taking advantage of their disadvantage for personal interest.

The narratives about their lives are hard and full of struggles. The high cost of living and the lack of skills and language proficiency defer these refugees to adjusting themselves to local multiethnic communities. Additionally, the rejection of local communities, the exploitation they took over refugees results in extending the safety and security issues at stake. Previous pieces of literature note Rohingyas refugees in Malaysia face similar struggles and exploitation by local authorities. Such exploitation becomes rampant and unconquerable.

\section{Conclusion}

To sum up, our findings show the survival patterns experienced by Syrian Muslim refugees in Malaysia involve human security elements, including personal, political, economic, and community. Based on the findings, we conclude the critical issue that needs attention is to revise the form of assistantship available for refugees who seek temporary shelters in Malaysia. The government is not severe in managing refugees and has to be changed promptly because giving them places to stay absent of work permit, and other possible programs for life adjustment with local communities' results in depriving their lives even further. They are unable to work and to support their family, rent, and could not afford to send their children to school. They are left with no choice but to be beggars living on a street to survive. This situation is like giving them another war to battle without bombs and weapons but severe enough to make them suffer.

Education is essential for refugees' children to learn and to gain some skills. Access to education is the fundamental right of children. Such rights have to be given to all children regardless of lack of identification, proper document, or social status. Education is their future that would allow them to mobilize their skills, knowledge, and social status. However, if access to education involves specific costs, a concerted effort from the government, NGOs, and UNHCR can seek private philanthropists to sponsor these children.

The worst circumstances are when some irresponsible Malaysian authorities take advantage of the refugees. They have no channel to make a report and face a deadlock in their life. This study suggests that NGOs focus on delegating help in certain humanitarian aspects such as foods, health screening for general and psychological evaluation, and education. A special helpline must be installed to allow refugees to channel their issues directly to a particular representative unit for further 
action. Such a helpline is necessary to attend exploitation, safety, and security threat refugees are dealing with in their daily encounters. For the health provision, refugees need to seek psychiatric assessment to threaten war-trauma and mental illness. The health services on trauma and mental illness are standard in refugees' camps of Jordan, Lebanon, and Turkey.

Moreover, in Europe, Canada, and Germany, NGOs are equipped with such trauma and mental illness expertise to treat refugees. A study by Adam Kersch and Joanna Mishtal shared the NGO Association Recreative e Cultural Italians (ARCI) advocate for the law to ensure refugees detained by the local authority are given due process rights at the court $^{41}$. On the other hand, MacTavish reveals the case of sexual harassment encounters at refugee camps, and it is the rights of NGO representatives to report such incidents faced by female refugees at camps in Vancouver, Canada, and Zaatari, Jordan, because female refugees are scared to report such harassment and physically abused $^{42}$.

The Malaysian government has to work seriously with NGOs and UNHCR in providing an organized system to manage the influx of refugees. Although Malaysia is yet to be a signatory to the refugee convention, humanitarian aids have been the forte of this country since the Bidong Island of Vietnamese refugees, followed by Bosnians, Rohingyas, and now Syrians. A proper refugee management system will allow Malaysia to be respected and simultaneously guarantee the safety and security of refugees who seek shelter and hope to begin their new life.

\section{References}

\section{Books}

Acharya, Amitav, 'Human Security' in John Baylis, Steve Smith and Patricia Owens, The Globalization of World Politics: An Introduction to International Relations (United Kingdom: Oxford University Press, 2017)

Baylis, John, Steve Smith and Patricia Owens, 'The Globalization of World Politics. An Introduction to International Relations', in International and Global Security (United Kingdom: Oxford University Press, 2017)

Daud, Sity and Zarina Othman, Politik dan Keselamatan (Bangi: Penerbit Universiti Kebangsaan Malaysia, 2005)

Daud, Sity, Zarina Othman and Rashila Ramli, Human Security \& Peace in Archipelagic Southeast Asia (Bangi: Penerbit Universiti Kebangsaan Malaysia, 2015)

Idris, Nor Azizan, 'Dari Pendekatan Realisme ke Perspektif Kritikal: Menyelusuri Kajian Keselamatan Semasa dan Pasca Perang Dingin.', in Keselamatan Nasional Malaysia (Bangi: Universiti Kebangsaan Malaysia, 2012)

James, Paul, 'Human Security as a Left-Over of Military Security, or as Integral to the Human Condition', in Human Security and Japan's Triple Disaster (London: Routledge, 2014)

Mansbach, Richard W and Kirsten L Taylor, Introduction to Global Politics (New York: Routledge, 2008)

Ramli, Rashila and Nor Azizan Idris, 'Keselamatan Insan dalam Konteks Keselamatan Nasional: Isu dan Cabaran dalam Membina Indeks Keselamatan Insan Malaysia.', in Keselamatan Nasional
41 Adam Kersch and Joanna Mishtal, 'Asylum in Crisis: Migrant Policy, Entrapment, and the Role of NonGovernmental Organisations in Siracusa, Italy', Refugee Survey Quarterly, $35.4 \quad$ (2016), 97-121 <https://doi.org/10.1093/rsq/hdw017>.
${ }^{42}$ Mac'Tavish, 'Barriers of Reporting Sexual Violence in Syrian Refugee Camps' \{ unpublished magister thesis, Royal Roads University, School of Humanitarian Studies, 2017\}, p. 20 
Malaysia (Bangi: Penerbit Universiti Kebangsaan Malaysia, 2012)

Tracy, Sarah J., Qualitative Research Methods Collecting Evidence, Crafting Analysis, Communicating Impact (United Kingdom: Wiley-Blackwell, 2013)

Wolfers, Arnold, Discord and Collaboration: Essay on International Politics (Baltimore and London: Johns Hopkins University Press, 1962)

\section{Journals}

Ahmad, Abdullahi, Ayode, Zulkanain Abdul Rahim and Abdul Majid Hafiz Bin Mohamed, 'The Refugee Crisis in Southeast Asia: The Malaysian Experience', International Journal of Novel Research in Humanity and Social Sciences, 3.6 (2016), 80-90

Ali, Norazira 'Cabaran-Cabaran Pelarian Rohingya Muslim: Kajian Kes di Pulau Pinang', Social Sciences Postgraduate International Seminar (SSPIS), 13.2 (2014), 265-274

Baharuddin, Syahrul, Alam and Azlizan Mat Enh, 'Pelarian Vietnam : Satu Isu Global dalam Sejarah Hubungan Luar Malaysia', Journal of Nusantara Studies (JONUS), 3.1 (2018), $1-18$ $<$ https://doi.org/10.24200/jonus.vol3is s1pp1-18>

Bellany, Ian, 'Towards A Theory of International Security', Political Studies, $29.1 \quad$ (1981), 100-105 $<$ https://doi.org/10.1111/j.14679248.1981.tb01276.x >

Berti, Benedetta, 'The Syrian Refugee Crisis: Regional and Human Security Implications', Strategic Assessment, 17.4 (2015), 41-53

Biondi, Paolo, 'Human Security and External Burden-Sharing: The European Approach to Refugee Protection between Past and Present', International Journal of Human Rights, 20.2 (2016), 208-222 <https://doi.org/10.1080/13642987.20 15.1103522>
Edwards, Alice, 'Human Security and the Rights of Refugees: Transcending Territorial and Disciplinary Borders', Michigan Journal of International Law, 30.3 (2009), 763-807

Eid, Iyad, Muhammad and Rohaiza Rokis, 'The Barriers to Education among the Palestinian Refugee Children in Malaysia (Halangan Pendidikan di Kalangan Kanak-Kanak Pelarian Palestin di Malaysia', Journal of Islam in Asia, 16.2 (2019), 369-399 <https://doi.org/10.31436/jia.v16i2.714 $>$

Enh, Azlizan, Binti, Mat, 'Sumbangan dan Peranan Malaysia dalam Konflik BosniaSerbia 1992-1995', Sejarah, 17.17 (2009), 177-193

$<$ https://doi.org/10.22452/sejarah.vol1 7 no17.8>

Farruku, Eglantina, 'Redefining Human Security The Case of Albania', Annales. Etyka w Życiu Gospodarczym, 19.4 (2016), 96 <https://doi.org/10.18778/18992226.19.4.06>

Gasper, Des, 'Securing Humanity: Situating "Human Security" as Concept and Discourse', Journal of Human Development, 6.2 (2005), 221-245 <https://doi.org/10.1080/14649880500 120558>

Hamzah, Intan, Suria and others, 'Migrasi Rentas Sempadan Etnik Rohingya dan Implikasi terhadap Malaysia', Sains Insani, $01.01 \quad$ (2016), 36-43 $<$ http://sainsinsani.com/issues/>.

Ispas, Lucia, Alin Cîrdei and Catalin Negoescu, 'The Concept of Human Security in International Relations', Land Forces Academy Review, 16.1 (2011), 11-19

Kersch, Adam and Joanna Mishtal, 'Asylum in Crisis: Migrant Policy, Entrapment, and the Role of Non-Governmental Organisations in Siracusa, Italy', Refugee Survey Quarterly, 35.4 (2016), 97-121 $<$ https://doi.org/10.1093/rsq/hdw017 $>$

Maguire, Moira and Brid Delahunt, 'Doing a Thematic Analysis: A Practical, Step-by- 
Step Guide for Learning and Teaching Scholars. All Ireland Journal of Teaching and Learning in Higher Education', All Ireland Journal of Teaching and Learning in Higher Education n (AISHE-J), 8.3 (2017), 3351-33514

Makinda, Samuel, M., 'Security and Sovereignty in the Asia-Pacific', Contemporary Southeast Asia, $23.3 \quad$ (2001), 401-419 $<$ https://doi.org/10.1355/cs23-3b >

Newman, Edward, 'Critical Human Security Studies', Review of International Studies, 36.1 (2010),77-94

<https://doi.org/10.1017/S0260210509 990519>

Odutayo, Aramide, 'Human Security and the International Refugee Crisis', Journal of Global Ethics, 12.3 (2016), 365-379. <https://doi.org/10.1080/17449626.20 16.1251484>

Paris, Roland, 'Human Security: Paradigm Shift or Hot Air?', International Security, 26.2 (2001), $87-102$ <https://doi.org/10.1162/01622880175 3191141>

Sokov, Ilya, 'Human Security as the Universal Value', Journal of Human Security, 8.1 (2012), 68-79

Treinovskis, Janis, Teivans- and Nikolajs Jefimovs, 'State National Security: Aspect of Recorded Crime', Journal of Security and Sustainability Issues, 2.2 (2012),41-48 $<$ https://doi.org/10.9770/jssi.2012.2.2

(4)>
Voothayakumar, Divaghar and Khadijah Alavi, 'Meneroka Kesejahteraan Sosial Karen dan Rohingya di Sekolah Pelarian Myanmar di Chow Kit", Asian People Journal, 2.1 (2019), 1-11

Wahab, Andika, A.,'The Colours of Exploitation: Smuggling of Rohingyas from Myanmar to Malaysia', Akademika, $88.1 \quad$ (2018), 5-16 <https://doi.org/10.17576/akad-20188801-01>

\section{Thesis}

Mac'Tavish, 'Barriers of Reporting Sexual Violence $\mathrm{n}$ Syrian Refugee Camps' \{unpublished magister thesis, Royal Roads University, School of Humanitarian Studies, 2017\}

\section{Interview}

Bahar, Fiza (Executive of project management), Interview $\{20$ February 2019\}

Informan A (Syrian refugee), Interview $\{26$ February 2019\}

Informant B (Syrian refugee), Interview \{20 June $2019\}$

Informant C (Syrian refugee), Interview $\{24$ February 2019\}

Sazli, Hasrol (Principal of Jasmine ash-Sham's school), Interview $\{20$ February 2019$\}$ 